\title{
Strategi Menurunkan Kematian Ibu Karena Preeklamsi dan Eklamsi
}

\author{
Johanes C. Mose \\ Departemen Obstetri \& Ginekologi Fakultas Kedokteran Universitas Padjadjaran/Rumah \\ Sakit Dr.Hasan Sadikin Bandung \\ Korespondensi: Johanes C. Mose. Email: jcmose07@yahoo.com
}

\begin{abstract}
Abstrak
Tujuan: Menyimpulkan beberapa hasil penelitian tentang preeklamsi dan upaya menurunkan kematian ibu di negara maju maupun berkembang termasuk di Indonesia dan RSHS Bandung untuk menyusun strategi menurunkan kematian ibu karena preeklamsi.

Metode: Dilakukan penelitian potong silang dengan rancangan observasional analitik dengan membandingkan data ibu hamil dengan preeklamsi/eklamsi yang melahirkan di RS Hasan sadikin Bandung periode Maret sampai September 2012 (sebelum JKN) dan 1 Januari 2016 sampai 31 Desember 2017(saat JKN dilaksanakan). Data dianalisis menggunakan uji statistik chi kuadrat untuk membandingkan perbedaan dengan kemaknaan nilai $\mathrm{p}<$ 0,05 .

Hasil: Terjadi kenaikan prevalensi preeklamsi dari 15,53\% sebelum JKN, menjadi 25,04\% saat JKN dilaksanakan. Terjadi peningkatan prevalensi preeklmasi menurut usia ibu, usia kehamilan, paritas, tingkat pendidikan, jumlah ANC, dan penyakit penyerta hipertensi dan kelainan jantung sebelum dan saat JKN dilaksanakan.

Diskusi : Strategi menurunkan kematian ibu karena preeklamsi/eklamsi, adalah : mendukung program pemerintah untuk mengatasi kemiskinan, pendidikan dan kesulitan transportasi; melaksanakan program sosialisasi kepada masyarakat tentang tanda dan gejala preeklamsi; deteksi dini kelompok risiko dan diagnosis PE dengan pengukuran tekanan darah dan proteinuria serta pemberian pencegahan dengan aspirin dosis rendah dan kalsium; pelatihan pemeriksaan Doppler arteri uterina untuk SpOG serta sosialisasi protokol pengelolaan PE, dan pelatihan 'preeclampsia special team' di RS rujukan.
\end{abstract}

Kata kunci : preeklamsi, kematian ibu, strategi menurunkan kematian ibu.

\section{Strategies for Reducing Maternal Mortality Due to Preeclampsia and Eclampsia}

\begin{abstract}
Objectives: To compile the result of studies on preeclampsia-eclampsia and strategies to reduce its maternal mortalities conducted in western and developing countries including Indonesia and Bandung aiming at developing strategies for reducing maternal mortality due to preeclampsia and eclampsia.

Method: This is a cross sectional analytic survey by taking the data from medical record to compare and analyze data of mothers with preeclampsia-eclampsia who delivered at Dr. Hasan Sadikin General Hospital Bandung from March to September 2012 (before the implementation of National Health Insurance Program-NHIP) and from January 2016 to December 2017(during the implementation of NHIP). Data was analyzed by mean of Chi-square test and significant difference criteria of $p<0.05$.

Results: There was a significant increase $(p<0.05)$ in prevalence of preeclampsia before $(15,53 \%)$ and during $(25,04 \%)$ the implementation of NHIP. There was a significant increase $(p<0.05)$ of incidence by maternal age, age of pregnancy, multiparity, low educational level, ANC of $>4$, and evidence of hypertension and cardiac complications before and during the implementation of NHIP.

Discussion : The strategies for reducing maternal mortality due to preeclampsia are as follows : supporting the government programs to overcome poverty, education and transportation; socializing signs and symptoms of preeclampsia to the community; early detection of risk factors, blood pressure measurement and urine protein followed by administration of low dose aspirin and calcium tablets for prevention; training on Doppler examination of uterine arteries for OBGYN specialist and socializing standard guidelines and protocol for the management of preeclampsia; and training for a 'preeclampsia special team'in referral hospitals.
\end{abstract}

Key words: preeclampsia, maternal mortality, strategy for reducing maternal mortality. 


\section{Pendahuluan}

Angka kematian ibu di Indonesia masih cukup tinggi. Survei Angka Sensus (SUPAS) tahun 2015, melaporkan angka kematian ibu (AKI) berkisar 305 per 100.000 kelahiran. Dari 14.640 total kematian ibu yang dilaporkan hanya 4.999 , berarti ada 9.641 yang tidak dilaporkan ke pusat. Dari data tersebut, ada 83.447 kematian ibu di desa maupun kelurahan, sementara di Puskesmas ada 9.825 kematian ibu, dan 2.868 kematian ibu di rumah sakit. ${ }^{(1)}$

Lebih jauh lagi Dirjen Kesmas, Kemenkes pada Rakernas 2019 di Serpong pada tanggal 13 Februari 2019, memaparkan bahwa, tempat kematian ibu yang terjadi, adalah di rumah sakit $77 \%$, di rumah $15,6 \%$, di perjalanan ke fasilitas pelayanan kesehatan $4,1 \%$, di fasilitas kesehatan lainnya $2,5 \%$ dan kematian ibu di tempat lainnya sebanyak $0,8 \%$. $^{(1)}$

Penyebab utama kematian ibu telah mengalami perubahan, sbb: Akibat gangguan hipertensi sebanyak $33,07 \%$, perdarahan obstetrik $27.03 \%$, komplikasi non obstetrik $15.7 \%$, komplikasi obstetrik lainnya $12.04 \%$, infeksi pada kehamilan $6.06 \%$ dan penyebab lainnya $4.81 \%$. $^{(1)}$

Dirjen Kesmas Kirana Pritasari, memaparkan kerangka konsep kesehatan, diantaranya tentang ketersediaan layanan kesehatan yang berkualitas, peningkatan penggunaan layanan, dan pemanfaatan JKN oleh masyarakat. ${ }^{(1)}$

Upaya penurunan AKI termasuk akibat preeklamsi/eklamsi sudah lama menjadi menjadi program unggulan dari pelbagai institusi dunia (WHO, UNICEF, UNFPA) maupun pelbagai pemerintahan Negara maju maupun berkembang. $(2,3,4,5,6,7,8)$

Evaluasi kematian ibu terutama akibat preeklamsi dan eklamsi di Indonesia oleh Himpunan Kedokteran Fetomaternal

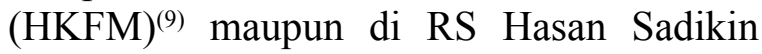
(RSHS) Bandung ${ }^{(10)}$ juga digunakan untuk menjadi dasar pertimbangan usulan strategi penurunan kematian ibu akibat preeklamsi ini.

Penelitian ini bertujuan untuk merangkum beberapa hasil penelitian tentang preeklamsi dan upaya menurunkan kematian ibu di negara maju maupun berkembang termasuk di Indonesia dan RSHS Bandung untuk mengusulkan strategi menurunkan kejadian kematian ibu karena preeklamsi.

\section{Metode}

Untuk mendapatkan dasar bagi penyusunan strategi menurunkan kematian ibu akibat preeklamsi di Indonesia, maka dikumpulkan pelbagai hasil penelitian dari negara maju maupun berkembang. Sebagai rujukan utama penulisan ini, disampaikan kembali sebagian dari hasil penelitian Irene Leha, Johanes C.Mose, dkk (10) yang membandingkan faktor determinan dan luaran preeklamsi pada saat sebelum dan saat program Jaringan Kesehatan nasional (JKN) dilaksanakan.

Seperti sudah diketahui bahwa program JKN dimulai sejak 1 januari 2014.

Penelitian ini merupakan penelitian potongsilang dengan rancangan observasional analitik dengan membandingkan data ibu hamil dengan preeklamsi/eklamsi yang melahirkan di RS Hasan sadikin Bandung periode Maret sampai September 2012 (sebelum JKN) dan 1 Januari 2016 sampai 31 Desember 2017(saat JKN dilaksanakan). Data dianalisis menggunakan uji statistik chi kuadrat untuk membandingkan perbedaan dengan kemaknaan nilai $\mathrm{p}<0,05$.

\section{Hasil}

Selama periode pertama (sebelum program JKN) ditemukan 1704 kelahiran, dibandingkan dengan periode kedua (saat dilaksanakan program JKN) sebesar 4929 kelahiran. 
Tabel 1 Distribusi Preeklamsi di RSUP Dr. Hasan Sadikin Bandung Periode Sebelum dan Saat Program JKN Dilaksanakan

\begin{tabular}{lccc}
\hline \multirow{2}{*}{ Periode } & \multicolumn{2}{c}{ Jumlah Kasus } & $\%$ \\
\cline { 2 - 3 } & Preeklamsi & Non Preeklamsi & \\
\hline Sebelum program JKN & 229 & 1475 & 15,53 \\
Saat program JKN & 987 & 3942 & 25,04 \\
\hline
\end{tabular}

Tabel 2 Perbandingan Faktor Determinan (Karakteristik dan Faktor Risiko) Preeklamsi antara Periode Sebelum dan Saat Program JKN Dilaksanakan

\begin{tabular}{|c|c|c|c|c|c|c|c|}
\hline \multirow[b]{2}{*}{ Karakteristik } & \multicolumn{2}{|c|}{2012} & \multirow[t]{2}{*}{$\% \mathrm{PE}$} & \multicolumn{2}{|c|}{ 2016-2017 } & \multirow[t]{2}{*}{$\% \mathrm{PE}$} & \multirow[b]{2}{*}{ Nilai $p^{*}$} \\
\hline & PE & Non-PE & & PE & Non-PE & & \\
\hline \multicolumn{8}{|l|}{ Usia ibu (Th) : } \\
\hline$<20$ & 18 & 154 & 10,46 & 78 & 411 & 15,95 & 0,079 \\
\hline $20-35$ & 153 & 1062 & 12,59 & 605 & 2844 & 17,54 & $<0,001$ \\
\hline$>35$ & 58 & 259 & 18,30 & 304 & 687 & 30,68 & $<0,001$ \\
\hline \multicolumn{8}{|l|}{ Usia kehamilan : } \\
\hline$<34$ minggu & 51 & 124 & 29,14 & 366 & 952 & 27,77 & 0,703 \\
\hline$\geq 34$ minggu & 178 & 1351 & 11,64 & 621 & 2990 & 17,20 & $<0,001$ \\
\hline \multicolumn{8}{|l|}{ Paritas : } \\
\hline Primipara & 103 & 665 & 13,41 & 305 & 1573 & 16,24 & 0,067 \\
\hline Multipara & 126 & 810 & 13,46 & 682 & 2369 & 22,35 & $<0,001$ \\
\hline \multicolumn{8}{|l|}{ Pendidikan: } \\
\hline Dasar & 133 & 846 & 13,58 & 480 & 1545 & 23,70 & $<0,001$ \\
\hline Menengah & 81 & 510 & 13,70 & 443 & 2087 & 17,51 & 0,026 \\
\hline Tinggi & 15 & 119 & 11,19 & 64 & 310 & 17,11 & 0,105 \\
\hline \multicolumn{8}{|l|}{ Antenatal Care: } \\
\hline$>4$ & 188 & 1297 & 12,66 & 663 & 2954 & 18,33 & $<0,001$ \\
\hline$\leq 4$ & 41 & 178 & 18,72 & 324 & 988 & 24,69 & 0,055 \\
\hline \multicolumn{8}{|l|}{ Penyakit penyerta : } \\
\hline Hipertensi & 34 & 77 & 30,63 & 434 & 5 & 98,86 & $<0,001$ \\
\hline DM & 5 & 14 & 23,32 & 4 & 4 & 50,00 & 0,226 \\
\hline Gangguan Kardio & 4 & 17 & 19,05 & 44 & 20 & 68,75 & $<0,001$ \\
\hline Gangguan ginjal & - & - & - & 6 & 1 & 85,71 & 0,917 \\
\hline
\end{tabular}

Tabel 1 memperlihatkan bahwa telah terjadi kenaikan prevalensi preeklamsi dari $15,53 \%$ sebelum JKN, menjadi $25,04 \%$ saat JKN dilaksanakan.

Tabel 2 memperlihatkan bahwa terjadi peningkatan bermakna kejadian PE pada kelompok usia 20-35 tahun, dari 12,59\% menjadi $17,54 \%$.

Prevalensi preeklmasi awitan dini (PEAD) sebesar $29,14 \%$ pada periode pertama dibandingkan periode kedua sebesar $27,77 \%$. Terjadi peningkatan bermakna 
Tabel 3 Perbandingan Cara Persalinan Ibu Preeklamsi antara Periode Sebelum dan Saat Program JKN Dilaksanakan

\begin{tabular}{|c|c|c|c|c|c|c|c|}
\hline \multirow[b]{2}{*}{ Jenis Persalinan } & \multicolumn{2}{|c|}{2012} & \multirow[t]{2}{*}{$\% \mathrm{PE}$} & \multicolumn{2}{|c|}{ 2016-2017 } & \multirow[t]{2}{*}{$\% \mathrm{PE}$} & \multirow[b]{2}{*}{ Nilai $p^{*}$} \\
\hline & PE & Non-PE & & PE & Non-PE. & & \\
\hline Spontan & 66 & 894 & 6,88 & 140 & 2232 & 5,90 & 0,291 \\
\hline Ekstraksi Forceps & 40 & 35 & 53,33 & 228 & 52 & 81,43 & $\infty, 001$ \\
\hline Ekstraksi Vacum & - & 57 & 0 & - & 76 & 0 & - \\
\hline Seksio Sesarea & 123 & 489 & 20,10 & 615 & 1583 & 27,98 & $<0,001$ \\
\hline
\end{tabular}

Tabel 4 Perbandingan Mortalitas Ibu Preeklamsi Antara Periode Sebelum dan Saat Program JKN Dilaksanakan

\begin{tabular}{|c|c|c|c|c|c|c|c|}
\hline \multirow[t]{2}{*}{ Kasus } & \multicolumn{2}{|c|}{$\begin{array}{c}\text { Sebelum Program } \\
\text { JKN }\end{array}$} & \multirow[t]{2}{*}{$\begin{array}{c}\% \\
\text { (Meninggal) }\end{array}$} & \multicolumn{2}{|c|}{ Saat Program JKN } & \multirow[t]{2}{*}{$\begin{array}{c}\% \\
\text { (Meninggal) }\end{array}$} & \multirow[t]{2}{*}{ Nilai $p^{3}$} \\
\hline & Meninggal & Hidup & & Meninggal & Hidup & & \\
\hline Precklamsi & 8 & 221 & 3,49 & 24 & 963 & 2,43 & 0,366 \\
\hline Non-Precklamsi & 4 & 1471 & 0,27 & 21 & 3921 & 0,53 & 0,206 \\
\hline
\end{tabular}

kejadian preeklamsi awitan lambat (PEAL) dari $11,64 \%$ pada periode pertama menjadi 17,20 pada periode kedua.

Terjadi peningkatan bermakna prevalensi pada multipara dari $13,46 \%$ pada periode pertama menjadi $22,23 \%$ pada periode kedua.

Prevalensi kejadian PE yang berpendidikan rendah, meningkat secara bermakna dari $13,58 \%$ pada periode pertama menjadi $23,70 \%$ pada periode kedua.

Terjadi peningkatan bermakna prevalensi ANC $>4$ sebesar 12,66\% pada periode pertama, menjadi $18,33 \%$ pada periode kedua.

Preeklamsi yang disertai kelainan jantung meningkat secara bermakna dari $19,05 \%$ pada periode pertama menjadi $68,75 \%$ pada periode kedua.

Tabel 3 memperlihatkan bahwa, terjadi peningkatan bermakna cara persalinan secara ekstraksi forceps $(53,33 \%$ vs $81,43 \%)$ dan secara seksio sesarea $(20,10 \%$ vs $27,98 \%)$

Tabel 4 memperlihatkan bahwa tidak terjadi penurunan bermakna persentasi kematian ibu akibat preeklamsi pada kedua periode $(3,49 \%$ vs $2,43 \%)$

\section{Pembahasan}

Dari hasil penelitian diatas dan beberapa penelitian yang disampaikan baik diluar maupun dalam negeri Indonesia, dapat ditarik beberapa masalah, sbb:

Masalah kematian ibu di dunia dan strategi menurunkan angka kematian ibu di Negara maju, antara lain :

1. Kematian ibu berhubungan dengan hak azasi manusia (untuk memperoleh kehidupan, pendidikan, persamaan hak dan tanpa perbedaan) ${ }^{(2)}$

2. Faktor yang sangat berperan pada tingginya kematian ibu karena preeklamsi, adalah : kemiskinan, jarak ke fasilitas kesehatan yang jauh, kurangnya informasi tentang gejala dan upaya deteksi dini, kualitas pelayanan obstetri yang kurang, dan kebiasaan serta budaya yang tidak mendukung. ${ }^{(7)}$

3. Strategi menurunkan kematian ibu harus melibatkan program dan 
kebijakan bersama yang terpadu antara pelbagai ahli dibidangnya dengan pemerintah. $^{(2)}$

4. Diperlukan adanya komitmen bersama secara politis dan hukum diantara pemegang kekuasaan. ${ }^{(2)}$

5. Kunci keberhasilan penurunan AKI di Negara maju adalah: kesadaran akan besarnya masalah, pemahaman bersama bahwa penyebab utama kematian ibu dapat dicegah, dan kemampuan untuk mengerakkan para professional dan masyarakat umum..$^{(2)}$

6. Percepatan penurunan AKI di negara maju tergantung pada: profesionalisme dan keterampilan penolong persalinan, kelengkapan dan kecanggihan alat kesehatan, tanggung jawab para pembuat kebijakan dan keterampilan penolong persalinan menurut standar yang baku. ${ }^{(2)}$

7. Penggunaan uji diagnostik/ marka untuk deteksi dini, rujukan yang tepat ke tingkat pelayanan yang lebih tinggi, induksi persalinan, serta persalinan dengan seksio sesarea akan menurunkan AKI dengan jelas. ${ }^{(4)}$

8. Penanganan kasus preeklamsi/eklamsi secara aktif sesuai standar protokol oleh tim yang sudah terlatih di rumah sakit, akan menurunkan AKI secara bermakna. ${ }^{(5)}$

9. Peningkatan tingkat pendidikan wanita, penggunaan paduan baku penanganan preeklamsi berat/eklamsi serta pengunaan obat antihipertensi yang tepat, akan menurunkan AKI secara bermakna. ${ }^{(6)}$

10. Pencegahan preeklamsi pada kelompok risiko tinggi ( riwayat $\mathrm{PE}$, hipertensi kronis, pregestasional DM, maternal BMI $>30 \mathrm{~kg} / \mathrm{m}^{2}$, APS, hamil dengan IVF/ assisted reproduction) dilakukan pemberian aspirin dosis rendah (75-162 $\mathrm{mg} /$ hari) bersama dengan kalsium $(1,2-$ 2,5 g/hari) dimulai sejak kehamilan $<$
16 minggu. ${ }^{(11)}$

11. Ibu dengan preeklamsi tanpa komplikasi harus dilahirkan pada usia kehamilan $\geq 37$ minggu, atau apabila mengalami komplikasi, sbb: preeklamsi berat yg gagal terapi dengan antihipertensi standar, trombositopeni progresif, abnormal fungsi ginjal dan hati yg progresif, edema paru, gejala serebral (sakit kepala hebat, scotoma, atau kejang/eklamsi), gawat janin..$^{(1)}$

Masalah kematian ibu (terutama preeklamsi/ eklamsi) di Indonesia :

1. Angka kematian ibu (AKI) di Indonesia (Supas 2015), sekitar 305 per 100.000 kelahiran. ${ }^{(1)}$

2. Penyebab utama kematian ibu adalah Hipertensi (termasuk preeklamsi/ eklamsi), sebesar 33,07\%.(1)

3. Tempat terjadinya kematian ibu, terutama di Rumah Sakit, sebesar 77\%. (1)

4. Angka kejadian preeklamsi semakin meningkat dan menjadi penyebab utama kematian ibu.(table 1)

5. Kejadian preeklamsi terbanyak pada PEAL, multipara, pendidikan rendah, PNC $>4$, disertai dengan kelainan jantung.(table 2)

6. Persalinan dengan seksio saesarea 56\%, perlu perawatan di ICU (11\%), 40\% perawatan di $\mathrm{HCU}, 93 \%$ memerlukan perawatan di RS $>2$ hari ( yang tidak di biayai oleh BPJS). ${ }^{(9)}$

\section{Simpulan}

Dari rangkuman masalah dan upaya penanggulangan preeklamsi pada pembahasan diatas, dapat ditarik beberapa langkah sebagai strategi untuk menurunkan kematian ibu akibat preeklamsi, sbb:

1. Mendukung program pemerintah untuk 
mengatasi kemiskinan, pendidikan yang rendah, serta kesulitan akses/ transportasi ke pusat kesehatan/rujukan yang lebih tinggi.

2. Mengatasi ketidak-tahuan akan gejala dini dan faktor risiko PE dengan melaksanakan program sosialisasi ke masyarakat umum, termasuk informasi tentang nutrisi/zat gizi yang baik, pola hidup, serta tindak lanjut untuk segera memeriksakan kehamilannya.

3. Pemeriksaan rutin pengukuran tekanan darah dan proteinuria di fasilitas kesehatan primer serta pemberian aspirin dosis rendah (75-162 $\mathrm{mg} / \mathrm{hari})$ dan kalsium (1,2-2,5 g/hari) pada kelompok risiko tinggi (riwayat $\mathrm{PE}$, hipertensi kronis, pregestasional DM, maternal BMI $>30 \mathrm{~kg} / \mathrm{m}^{2}$, APS, hamil dengan IVF/ assisted reproduction)

4. Pelatihan para SpOG di fasilitas kesehatan sekunder dan tertier untuk deteksi dini dengan pemeriksaan Doppler arteri uterina serta penanganan obstetri pada preeklamsi dengan dan tanpa komplikasi menurut protokol yang berlaku.

5. Perhatian yang khusus diberikan pada penanganan kasus preeklamsi/eklamsi yang dirujuk ke rumah sakit dengan memfasilitasi jalur rujukan cepat/ jalur khusus dan di tangani oleh "special team" yang terlatih dengan protokol dan prasarana yg khusus.

\section{Daftar Pustaka}

1. Rakernas 2019, Dirjen Kesmas. Paparkan Strategi Penurunan AKI dan Neonatal. Direktorat Jenderal Kementrian Kesehatan RI. 23 Februari 2020.

2. Hunt P, Judith B de Mesquita. Reducing maternal mortality. The contribution of the right to the highest attainable standard of health. New York USA: United Nation Population Fund 2011
3. De Brouwere V, Tonglet R, Van Lerberghe W. Strategies for reducing maternal mortality in developing countries : What can learn from history of the industrialized west ? Tropical Med and Internat Health 1998; 3: 771-82.

4. Goldenberg RL, Jones B, Griffin JB, Rouse DJ, Kamath-Rayne B, Trivedi N, et al. Reducing maternal mortality from preeclampsia and eclampsia in lowresurse countries-What should work ? Acta Obstet Gynecol Scan 2015;94:14855.

5. Herrera JA, Herrera-Medina R, HerreraEscobar JP, Nieto-Diaz A. Reducing of maternal mortality due to preeclampsia in Colombia-an interrupted time-series analysis. Colomb Med (Cali) 2014;45:2531.

6. Keskinkilic B, Engin-Ustun Y, Sanisoglu S, Sahin Uygur D, Keskin HL, Karaahmetoglu S, et al. Maternal mortality due to hypertensive disorders in pregnancy, childbirth, and the puerperium between 2012 and 2015 in Turkey: A nation-based study. J Turk Ger Gynecol Assoc 2017;18:20-25.

7. Tsigas E. World Preeclampsia Day : Reducing preventable deaths from preeclampsia. Preeclampsia Foundation 2017.

8. National Institute of Health. Disparity of access and quality. Review of maternal mortality in five region in Indonesia. Research and Development MoH RIUNFPA 2012

9. Bachnas MA, Akbar MIA, Effendi JS, Mose JC, Dewantiningrum J, Kristanto $\mathrm{H}$, et al. The massive problem of preeclampsia in Indonesia: In need of a redisined national health care system. Pregnancy Hypertension 2018;13:S16

10. Leha I, Mose JC, Handono B, Deborah A, Zulfayanti, Husni Syam H. Perbandingan factor determinan dan luaran preeklamsi periode sebelum dan saat program 
jaminan kesehatan nasional dilaksanakan. Obgynia 2019; 2:60-6.

11. Brown MA, Magee LA, Kenny LC, KarumanchiA, McCarthyFP, Saito S, etal. The hypertensive disorders of pregnancy : ISSHP classification, diagnosis \& management recommendations for international practice. Pregnancy Hypertension 2018;13:291-310. 